\title{
Nitrogen fixation, plant growth and yield enhancements by diazotrophic growth-promoting bacteria in two cultivars of chickpea (Cicer arietinum L.)
}

\author{
Subramaniam Gopalakrishnan*, Vadlamudi Srinivas, Srinivasan Samineni \\ International Crops Research Institute for the Semi-Arid Tropics (ICRISAT), Patancheru 502324, Telangana, India
}

\section{A R T I C L E I N F O}

\section{Keywords:}

Diazotrophs

Nitrogen fixation

Plant growth-promoting bacteria

Chickpea

\begin{abstract}
A B S T R A C T
A total of 11 rhizobia-like-bacteria, isolated from the nodules of chickpea, were characterized for nitrogen fixation potential and growth promoting ability. All the isolates nodulated chickpea, amplified nifH gene and fixed nitrogen but, four isolates (ICKM-9, ICKM-15, ICS-31 and ICS-32) were found to fix nitrogen more than 4.0 nmoles of ethylene $\mathrm{g}^{-1}$ fresh weight of nodules $\mathrm{h}^{-1}$. Under field conditions, seeds of chickpea varieties ICCV 2 and JG 11, when treated with the bacteria, enhanced the nodule number (up to $46 \%$ and $46 \%$ ), nodule mass (up to $76 \%$ and $50 \%$ ), shoot mass (up to $21 \%$ and $42 \%$ ) and grain yield (up to $27 \%$ and $25 \%$ ), respectively, over the un-inoculated control. At the harvest, organic carbon (up to $7 \%$ and $24 \%$ ), total nitrogen (up to $11 \%$ and $19 \%$ ) and available phosphorous (up to $14 \%$ and $29 \%$ ) were found enhanced, respectively, in the rhizosphere of ICCV2 and JG-11 treated with bacteria over the un-inoculated control. All the isolates produced plant growth-promoting traits including indole acetic acid, $\beta$-1,3-glucanase, hydro cyanic acid (except ICKM-17 and ICS-31) and siderophore (except ICS-31). The $16 \mathrm{~S}$ rDNA gene sequences of bacterial isolates of ICKM-1, ICKM-4, ICKM-7, ICKM-9, ICKM-12, ICKM-14, ICKM-15, ICKM-17, ICS-30, ICS-31 and ICS-32 showed maximum identity with Pantoea dispersa, Chryseobacterium indologenes, Pseudomonas geniculata, Stenotrophomonas pavanii, $P$. geniculata, $P$. geniculata, Stenotrophomonas maltophilia, Chryseobacterium sp., P. geniculata, Chryseobacterium indologenes and Stenotrophomonas acidaminiphila, respectively. This study indicates nodule-associated bacteria could be a valuable pool for improving nitrogen fixation and crop yields in chickpea.
\end{abstract}

\section{Introduction}

Chickpea (Cicer arietinum L.) is the second most important pulse crop grown around the world. It is grown in more than 55 countries on an area of about 14 million hectares during 2014 (FAOSTAT, 2017). India is the largest chickpea producing country with $71 \%$ of global chickpea production. Chickpea grain is mainly used as food because of its high protein (12.4-31.5\%), carbohydrate (52.4-70.9\%), minerals (such as phosphorous, calcium, magnesium, iron and zinc) and $\beta$-carotene contents (Awasthi et al., 1991). Global yield of chickpea has been relatively stagnant $\left(0.5\right.$ and $\left.1.0 \mathrm{t} \mathrm{ha}^{-1}\right)$ since last five decades (FAOSTAT, 2017) in spite of adopting conventional breeding and molecular approaches and extensively using synthetic fertilizers, pesticides and supplements. Productivity of chickpea may be considerably improved if the adverse effects of abiotic (climate and soil) and biotic (insect pests and pathogens) stresses are reduced. With the ever increasing cost of synthetic pesticides and fertilizers and concern over environmental pollution and/or degradation, there has been a resurgence of interest to develop eco-friendly methods of crop production and protection. The environment-friendly options include the use of plant growth-promoting (PGP) microbes, biocontrol potential microbes, animal wastes, botanicals and crop residues which serve as an alternative to synthetic fertilizers and pesticides (Rupela et al., 2005).

Rhizobacteria that benefit plant growth by producing plant growth regulators, enhancing the nutrient(s) availability, inducing root exudation and controlling phytopathogens are termed as PGP bacteria (Kloepper and Schroth, 1978). PGP bacteria actively colonize plant roots and increase plant growth and yield. Further, indigenous PGP bacteria help in substantially reducing the chemical inputs as they can easily acclimatize to the natural conditions and thus enhance the plantmicrobe interactions (Verma et al., 2013). PGP bacteria including species of Streptomyces, Pseudomonas, Bacillus, Azotobacter, Azospirillum, Acinetobacter, Enterobacter, Serratia and Brevibacterium have been reported to enhance plant growth and yield in chickpea (Weller et al., 2002; Singh et al., 2008; Soe et al., 2010; Gopalakrishnan et al., 2015a, 2016; Sreevidya and Gopalakrishnan, 2017). The mechanisms of PGP bacteria promoting plant growth and yield include nitrogen fixation, ability to synthesize molecules such as indole acetic acid, siderophores,

\footnotetext{
* Corresponding author.

E-mail address: s.gopalakrishnan@cgiar.org (S. Gopalakrishnan).
} 
organic acids and exopolysaccharides and solubilize phosphorus and other nutrients to enhance micronutrient uptake (Ahmad et al., 2008; Gopalakrishnan et al., 2014, 2016). Actively growing PGP bacteria are commonly found in the rhizosphere and rhizoplane as plants release root exudates that contains sugars, growth regulators, amino acids, organic acids, flavonoids, enzymes, fatty acids and vitamins (Uren, 2000). The major objective of this study was to identify diazotrophic PGP bacteria from the nodules of chickpea, which promote plant growth and enhance chickpea yield.

\section{Materials and methods}

\subsection{Root nodule bacteria isolation and preservation}

Healthy root nodules, collected from ICCV 2 and JG 11 varieties of chickpea grown at International Crops Research Institute for the SemiArid Tropics (ICRISAT), Patancheru, Hyderabad, India during December 2014, were surface sterilized with $2.5 \%$ sodium hypochlorite for $2 \mathrm{~min}$ and washed (5 times) with sterilized distilled water. They were aseptically crushed on yeast extract mannitol agar (YEMA) and incubated at $28{ }^{\circ} \mathrm{C}$ for 4 days. At the end of incubation, a single colony representing from each nodule was picked and further purified on YEMA plates. The most prominent isolates were maintained on YEMA slants at $4{ }^{\circ} \mathrm{C}$ for further studies.

\subsection{Symbiotic tests}

To investigate nitrogen fixing ability of rhizobacteria, the pure cultures of isolates were grown to log phase and genomic DNA isolated according to Bazzicalupo and Fani (1995). The genomic DNA was used for the amplification of nifH gene using primers: nifH for (5'-TAY GGN AAR GGN GGHATY GGY ATC- $3^{\prime}$ ) and nifH rev (5'-ATR TTR TTN GCN GCR TAV ABB GCC ATC AT-3') (Sarita et al., 2007). The PCR reaction mixture $(25 \mu \mathrm{l})$ contained $2 \mu \mathrm{l}$ template DNA $(0.1-0.14 \mu \mathrm{g} / \mu \mathrm{l}), 0.5 \mu \mathrm{l}$

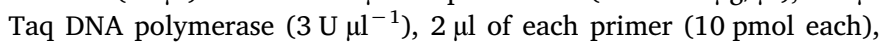
$0.5 \mu \mathrm{l}$ dNTP mixture $(10 \mathrm{mM}), 10 \times$ PCR assay buffer with $25 \mathrm{mM}$ $\mathrm{MgCl}_{2}(2.5 \mu \mathrm{l})$ and $15.5 \mu \mathrm{l}$ sterile ultra-pure water. PCR conditions were: denaturation at $95^{\circ} \mathrm{C}$ for $4 \mathrm{~min} ; 35$ cycles of denaturation at $94^{\circ} \mathrm{C}$ for $30 \mathrm{~s}$; annealing at $54{ }^{\circ} \mathrm{C}$ for $1 \mathrm{~min}$; extension at $72{ }^{\circ} \mathrm{C}$ for $6 \mathrm{~min}$. The PCR product was electrophorised on $2 \%$ agarose gel stained with ethidium bromide and photographed using Gel Documentation system (Syngene GBOX).

\subsubsection{Acetylene reduction activity}

Nitrogenase activity of rhizobacteria was measured by acetylene $\left(\mathrm{C}_{2} \mathrm{H}_{2}\right)$ reduction assay as per the protocols of Hardy et al. (1968) with slight modifications. The effect of bacterial culture for their nodulation potential was studied in greenhouse conditions. The experiment was laid with 12 treatments (11 nodule associated bacteria and one water inoculated negative control) in three replications. Chickpea seeds of ICCV 2 (acquired from chickpea breeding, ICRISAT) were surface sterilized with sodium hypochlorite $(2.5 \%$ for $3 \mathrm{~min})$ followed by ethanol ( $70 \%$ for $3 \mathrm{~min}$ ) and rinsed with sterile water ( 5 times). The surface sterilized seeds were transferred into culture of test bacterial isolates grown in YEM broth and kept for an hour. The treated seeds were dibbled in pots ( 6 seeds/pot but thinned to 3 after one week). Booster doses of bacterial cultures ( $5 \mathrm{ml}$ per seedling, $10^{8} \mathrm{CFU} \mathrm{ml}{ }^{-1}$ ) were given twice (at 10 and 20 days after sowing) by drenching the soil. At 35 days after sowing (DAS), plants were uprooted and the roots were separated. The roots, along with nodules, were washed gently to remove the soil particles and transferred into a glass bottle $(300 \mathrm{ml})$ and sealed. Thirty millilitres (v/v; 10\%) of air was drawn from the glass bottle, with a hypodermic needle and replaced with an equal volume of acetylene gas and incubated at room temperature for $1 \mathrm{~h}$. At the end of incubation, $5 \mathrm{ml}$ of gas drawn from the glass bottle was transferred into a vacutainer and stored at $4{ }^{\circ} \mathrm{C}$ until analysed in gas chromatograph
(GC). One $\mathrm{ml}$ of the above sample was injected into a GC (Agilent 7890B), equipped with a flam ionization detector (FID) to detect ethylene $\left(\mathrm{C}_{2} \mathrm{H}_{4}\right)$ and acetylene gas. The results were expressed as nmoles of ethylene gas formed $\mathrm{g}^{-1}$ nodule fresh weight $\mathrm{h}^{-1}$. Leaves were used for estimating total chlorophyll content as per the protocols of Hiscox and Israelstam (1979). Other growth parameters including shoot dry weight, root dry weight, nodule number and nodule dry weight were also determined.

\subsection{Field inoculation trial}

The field trial for two chickpea cultivars (ICCV 2 and JG 11; acquired from chickpea breeding, ICRISAT) was undertaken in 2014-2015 at ICRISAT, Patancheru $\left(17^{\circ} 30^{\prime} \mathrm{N} ; 7^{\circ} 16^{\prime} \mathrm{E}\right.$; altitude $549 \mathrm{~m}$ ), Hyderabad, India. Soils at the experimental site are classified as Vertisols with an alkaline $\mathrm{pH}(7.5-8.2)$ and an OC content of $0.4-0.5 \%$. The top $15 \mathrm{~cm}$ rhizosphere soil consists of $22 \mathrm{mg} \mathrm{kg}^{-1}$ soil of available $\mathrm{N}, 10 \mathrm{mg} \mathrm{kg}^{-1}$ soil of available $\mathrm{P}$ and $285 \mathrm{mg} \mathrm{kg}^{-1}$ soil of available K. Di-ammonium phosphate (DAP @ $20 \mathrm{~kg} \mathrm{ha}^{-1}$ ) was incorporated in the soil three days before sowing. The trial was conducted in a RCBD design with three replicates and subplot sizes of $4 \mathrm{~m} \times 3$ ridges. The selected root nodule bacteria were cultured individually on YEM broth at $28^{\circ} \mathrm{C}$ for four days. The seeds of chickpea (ICCV 2 and JG 11) were treated with the root nodule bacterium (individually; containing $10^{8} \mathrm{CFU} \mathrm{ml}{ }^{-1}$ ) for $45 \mathrm{~min}$ and sown immediately in rows $30 \mathrm{~cm}$ apart at a depth of 4-5 $\mathrm{cm}$ to achieve an estimated plant population of at least 25 plants $\mathrm{m}^{-2}$. Plants were inoculated with respective root nodule bacterium at root zone every 15 days till the flowering stage. Control seeds and plots were not treated with root nodule bacteria. No pesticide was sprayed during the cropping period, as no serious insect pest attacks or phytopathogens were observed. Weeding was done 20 days after sowing. The crop was harvested manually on 23 February 2015 at 35 DAS and observations on the number of nodule, nodule weight and shoot weight were recorded. At 60 DAS, observations were made on plant height, shoot weight, leaf weight and leaf number. At crop maturity, pod number, pod weight, seed weight, grain yield and stover yield were recorded. After harvest, rhizosphere soil samples (from top $15 \mathrm{~cm}$ of soil profile) were collected from both ICCV 2 and JG 11 plots and analysed for total nitrogen, available phosphorous and organic carbon as per the protocols of Novozamsky et al. (1983), Olsen and Sommers (1982) and Nelson and Sommers (1982), respectively.

\subsection{PGP traits of the root nodule bacteria}

The root nodule bacteria were characterized for their PGP traits including cellulase, lipase, protease, chitinase, indole acetic acid (IAA), $\beta$-1,3-glucanase, siderophore, hydrocyanic acid (HCN) and phosphorous solubilization. The trait for the production of cellulase (Hendricks et al., 1995), lipase (Bhattacharya et al., 2009) and protease (Bhattacharya et al., 2009) was studied as per the standard protocols. Chitinase production was studied by amending agar plates with colloidal chitin and mineral salts according to Hsu and Lockwood (1975). IAA, $\beta$-1,3-glucanase and siderophore were estimated as per Patten and Glick (2002), Singh et al. (1999) and Schwyn and Neilands (1987), respectively. One unit of $\beta-1,3$-glucanase activity was defined as the amount of enzyme that liberated $1 \mu \mathrm{mol}$ of glucose hour ${ }^{-1}$ at defined conditions. HCN was qualitatively assessed by the protocol described by Lorck (1948). For HCN production, the following scale was used: $0=$ no color change, 1 = light reddish brown, 2 = medium reddish brown and $3=$ dark reddish brown. Phosphorous solubilization was tested in National Botanical Research Institute's Phosphate (NBRIP) as per the methods of Nautiyal (1999).

\subsection{Molecular identification of the root nodule bacteria}

The selected root nodule bacteria were sent to Macrogen Inc. Seoul, 
Korea for identification by $16 \mathrm{~S}$ rDNA analysis. The sequences obtained from Macrogen Inc. were compared with similar sequences in GenBank, using the BLAST program (Altschul et al., 1990), aligned with the Clustal W software (Thompson et al., 1997) and the dendrogram inferred by Neighbor-joining method (Saitou and Nei, 1987). Bootstrap analysis was performed using the MEGA version 4 program to estimate the statistical stability of the branches in cluster with 1000 replications. The sequences were submitted to NCBI and accession numbers obtained.

\subsection{Statistical analysis}

For field studies, data were analysed by using analysis of variance (ANOVA), by SAS GLM (General Linear Model) procedure (SAS Institute 2002-08, SAS version 9.3) considering isolates and replication as fixed in randomized complete block design. Isolate means were tested for significance and compared using Fisher's protected least significant difference. For greenhouse study, data were analysed statistically by ANOVA and the mean values were compared at 5\% level of significance.

\section{Results}

\subsection{Root nodule bacteria isolation and preservation}

Totally 11 root nodule bacteria ICKM-1, ICKM-4, ICKM-7, ICKM-9, ICKM-12, ICKM-14, ICKM-15, ICKM-17, ICS-30, ICS-31 and ICS-32 were isolated from the healthy nodules of ICCV 2 and JG 11 chickpea varieties.

\subsection{Symbiotic tests of the root nodule bacteria}

The nitrogen fixing ability of all the 11 root nodule bacteria was demonstrated by nodulation and acetylene reduction assay (ARA). Under greenhouse conditions, all the 11 root nodule bacteria not only nodulated the chickpea plants (in ICCV 2) but also significantly enhanced the shoot dry weight (up to $33 \%$ ), root dry weight (up to 64\%), total chlorophyll content (up to $27 \%$; except ICKM-1), nodule number (up to $78 \%$ ) and nodule dry weight (up to $98 \%$ ) (Table 1). In the ARA, all the 11 root nodule bacteria exhibited nitrogenase activity. The nitrogenase activity ranged from 0.447 (ICKM-1) to 4.920 (ICKM-9) nmoles of ethylene/g fresh weight nodules/h. More than 4 nmoles of ethylene/g fresh weight nodules/h was observed in four root nodule bacteria ICKM-9, ICKM-15, ICS-31 and ICS-32, which is > 97\% increase compared to control (Table 1).

Amplification of nifH gene segment yielded the product of expected size (400 bp) from DNA template for all the 11 isolates indicating the presence of nitrogen fixing genes in these isolates.

\subsection{Field inoculation trial}

Under field conditions, in both cultivars (ICCV 2 and JG 11), significant increase in number of agronomic and soil mineral properties were noted in all the 11 root nodule bacteria treated plots over control. At 30 DAS, plots treated with root nodule bacteria, in both cultivars, enhanced the nodule number (up to $46 \%$ and $46 \%$ ), nodule dry weight (up to $76 \%$ and $50 \%$ ) and shoot dry weight (up to $21 \%$ and $42 \%$ ). At 60 DAS, there was rise in plant height (up to $16 \%$ and $12 \%$ ), shoot dry weight (up to $33 \%$ and $27 \%$ ), leaf dry weight (up to $33 \%$ and $35 \%$ ) and leaf area (up to $31 \%$ and $16 \%$ ), respectively, over the un-inoculated control plots (Tables 2 and 3). At grain maturity/harvest stage, the root nodule bacteria treated plots exhibited enhanced pod number (up to $27 \%$ and $31 \%$ ), pod dry weight (up to $28 \%$ and $35 \%$ ), seed weight (up to $30 \%$ and $34 \%$ ), grain yield (up to $27 \%$ and $25 \%$ ) and stover yield (up to $25 \%$ and $8 \%$ ), respectively, over the un-inoculated control plots (Table 4). At grain maturity/harvest, the rhizosphere soil from root nodule bacteria treated plots, enhanced organic carbon (up to $7 \%$ and $24 \%$ ), total $\mathrm{N}$ (up to $11 \%$ and $19 \%$ ) and available P (up to $14 \%$ and $29 \%$ ), respectively, over un-inoculated control plots (Table 5).

\subsection{PGP traits of the root nodule bacteria}

Under in vitro conditions, all the root nodule bacteria were found to produce cellulase, lipase, protease, IAA, $\beta$-1,3-glucanase, chitinase (except ICKM-1, ICKM-7, ICKM-15, ICS-30 and ICS-31), siderophore (except ICS-31) and HCN (except ICKM-17 and ICS-31) and six isolates solubilized P (except ICKM-1, ICKM-4, ICKM-14, ICKM-17 and ICS-32) (Table 6).

\subsection{Molecular identification of the root nodule bacteria}

The sequences obtained from Macrogen (1033 bp for ICKM-1, 1070 bp for ICKM-4, 992 bp for ICKM-7, 1482 bp for ICKM-9, 986 bp for ICKM-12, 1298 bp for ICKM-14, 1305 bp for ICKM-15, $1390 \mathrm{bp}$ for ICKM-17, 1000 bp for ICS-30, 901 bp for ICS-31 and 1474 bp for ICS32) were compared with similar sequences from GenBank, aligned and the dendrogram inferred (Fig. 1). The sequences of $16 \mathrm{~S}$ rDNA gene of the root nodule bacteria of ICKM-1, ICKM-4, ICKM-7, ICKM-9, ICKM-

Table 1

Nodulation and nitrogen fixation capabilities of the 11 PGP bacteria on high nodulating chickpea cultivar (ICCV 2) under greenhouse conditions- at 35 days after sowing.

\begin{tabular}{|c|c|c|c|c|c|c|}
\hline Isolates & $\begin{array}{l}\text { Shoot dry } \\
\text { weight } \\
\text { (g plant }^{-1} \text { ) }\end{array}$ & $\begin{array}{l}\text { Root dry } \\
\text { weight } \\
\text { (g plant }^{-1} \text { ) }\end{array}$ & $\begin{array}{l}\text { Total } \\
\text { chlorophyll } \\
\left(\mathrm{mg} \mathrm{l}^{-1}\right)\end{array}$ & $\begin{array}{l}\text { Nodule } \\
\text { number } \\
\text { (plant }^{-1} \text { ) }\end{array}$ & $\begin{array}{l}\text { Nodule dry } \\
\text { weight } \\
\text { (mg plant }^{-1} \text { ) }\end{array}$ & $\begin{array}{l}\text { ARA } \\
\mu \mathrm{mol} \\
(\mathrm{mg})\end{array}$ \\
\hline ICKM-1 & $0.887^{*}$ & 0.107 & 27.69 & $11.3^{*}$ & $13^{*}$ & $0.447^{*}$ \\
\hline ICKM-4 & $0.830^{*}$ & 0.113 & $39.61^{*}$ & $16.3^{*}$ & $20 *$ & $1.047^{*}$ \\
\hline ICKM-7 & $0.813^{*}$ & $0.150^{*}$ & $33.84^{*}$ & $16.4^{*}$ & $20 *$ & $1.397^{*}$ \\
\hline ICKM-9 & $0.950^{*}$ & $0.153^{*}$ & $33.83^{*}$ & $25.5^{*}$ & $30^{*}$ & $4.920^{*}$ \\
\hline ICKM-12 & $0.847^{*}$ & $0.197^{*}$ & $31.33^{*}$ & $22.9^{*}$ & $23^{*}$ & $2.770^{*}$ \\
\hline ICKM-14 & $0.870^{*}$ & $0.177^{*}$ & $37.63^{*}$ & $23.6^{*}$ & $20 *$ & $3.087^{*}$ \\
\hline ICKM-15 & $0.933^{*}$ & $0.163^{*}$ & $30.75^{*}$ & $26.6^{*}$ & $40 *$ & $4.483^{*}$ \\
\hline ICKM-17 & $1.073^{*}$ & $0.180^{*}$ & $31.93^{*}$ & $25.4^{*}$ & $40 *$ & $3.997^{*}$ \\
\hline ICS-30 & $0.917^{*}$ & $0.180^{*}$ & $34.60^{*}$ & $17.8^{*}$ & $20 *$ & $3.237^{*}$ \\
\hline ICS-31 & $1.017^{*}$ & $0.220^{*}$ & $30.93^{*}$ & $34.2^{*}$ & $30 *$ & $4.600^{*}$ \\
\hline ICS-32 & $0.933^{*}$ & $0.170^{*}$ & $29.89^{*}$ & $27.3^{*}$ & $40^{*}$ & $4.067^{*}$ \\
\hline Control & 0.723 & 0.080 & 28.89 & 7.7 & 1 & 0.097 \\
\hline Mean & 0.899 & 0.158 & 32.58 & 21.3 & 25 & 2.846 \\
\hline $\mathrm{SE} \pm$ & 0.0089 & 0.0139 & 0.049 & 0.50 & 1.3 & 0.0756 \\
\hline LSD (5\%) & 0.0259 & 0.0407 & 0.144 & 1.46 & 3.8 & 0.2218 \\
\hline $\mathrm{CV} \%$ & 2 & 15 & 1 & 4 & 9 & 5 \\
\hline
\end{tabular}

$* * *=$ Statistically significant at 0.05 compared to control. 
Table 2

Effect of the 11 PGP bacteria on nodules and shoot weight on two chickpea cultivars under field conditions- at 35 days after sowing.

\begin{tabular}{|c|c|c|c|c|c|c|}
\hline \multirow[b]{2}{*}{ Isolate } & \multicolumn{3}{|l|}{ ICCV 2} & \multicolumn{3}{|l|}{ JG 11} \\
\hline & $\begin{array}{l}\text { Nodule } \\
\text { number } \\
\text { (plant }^{-1} \text { ) }\end{array}$ & $\begin{array}{l}\text { Nodule } \\
\text { weight } \\
\text { (g plant }^{-1} \text { ) }\end{array}$ & $\begin{array}{l}\text { Shoot } \\
\text { weight } \\
\text { (g plant }^{-1} \text { ) }\end{array}$ & $\begin{array}{l}\text { Nodule } \\
\text { number } \\
\text { (plant }^{-1} \text { ) }\end{array}$ & $\begin{array}{l}\text { Nodule } \\
\text { weight } \\
\text { (g plant }^{-1} \text { ) }\end{array}$ & $\begin{array}{l}\text { Shoot } \\
\text { weight } \\
\text { (g plant }^{-1} \text { ) }\end{array}$ \\
\hline ICKM-1 & $27.3^{*}$ & $22.0^{*}$ & $4.03^{*}$ & 17.0 & 6.0 & $4.20 *$ \\
\hline ICKM-4 & 17.7 & $12.7^{*}$ & $4.00^{*}$ & 13.7 & 6.0 & $4.7^{*}$ \\
\hline ICKM-7 & 17.7 & 8.0 & $4.00 *$ & $19.7^{*}$ & 5.3 & $4.60 *$ \\
\hline ICKM-9 & $21.3^{*}$ & $17.0^{*}$ & $4.17^{*}$ & 13.0 & $10.7^{*}$ & $4.57^{*}$ \\
\hline ICKM-12 & $23.0^{*}$ & 8.0 & $4.33^{*}$ & $21.3^{*}$ & 6.0 & $4.27 *$ \\
\hline ICKM-14 & 16.3 & 8.7 & $3.87^{*}$ & $23.3^{*}$ & 5.3 & $5.43^{*}$ \\
\hline ICKM-15 & $21.0 *$ & $11.3^{*}$ & $4.03^{*}$ & 18.0 & 6.7 & 3.67 \\
\hline ICKM-17 & 18.0 & $13.3^{*}$ & $4.37 *$ & 16.3 & 6.7 & 3.93 \\
\hline ICS-30 & 16.7 & 10.0 & $4.07^{*}$ & 14.7 & 6.0 & 3.70 \\
\hline ICS-31 & $24.7^{*}$ & $11.3^{*}$ & 3.77 & 13.0 & 7.3 & 3.90 \\
\hline ICS-32 & 15.7 & 6.7 & $3.93^{*}$ & 12.7 & 6.0 & 4.03 \\
\hline Control & 14.7 & 5.3 & 3.47 & 12.7 & 5.3 & 3.17 \\
\hline Mean & 19.5 & 11.2 & 4.00 & 16.3 & 6.4 & 4.17 \\
\hline $\mathrm{SE} \pm$ & 2.20 & 1.79 & 0.138 & 2.14 & 0.93 & 0.328 \\
\hline LSD (5\%) & 6.45 & 5.24 & 0.406 & 6.26 & 2.74 & 0.963 \\
\hline CV\% & 20 & 28 & 6 & 23 & 25 & 14 \\
\hline
\end{tabular}

$\mathrm{SE}=$ Standard error; LSD = least significant differences; $\mathrm{CV}=$ coefficients of variation; * = statistically significant at 0.05 compared to control.

Table 3

Effect of the 11 PGP bacteria on agronomic performance on two chickpea cultivars under field conditions- at 60 days after sowing.

\begin{tabular}{|c|c|c|c|c|c|c|c|c|}
\hline \multirow[b]{2}{*}{ Isolate } & \multicolumn{4}{|l|}{ ICCV-2 } & \multicolumn{4}{|l|}{ JG-11 } \\
\hline & $\begin{array}{l}\text { Plant } \\
\text { height } \\
(\mathrm{cm})\end{array}$ & $\begin{array}{l}\text { Shoot } \\
\text { weight } \\
\text { (g plant }^{-1} \text { ) }\end{array}$ & $\begin{array}{l}\text { Leaf } \\
\text { weight } \\
\left.\text { (g plant }^{-1}\right)\end{array}$ & $\begin{array}{l}\text { Leaf } \\
\text { area }\left(\mathrm{m}^{2}\right. \\
\left.\text { plant }^{-1}\right)\end{array}$ & $\begin{array}{l}\text { Plant } \\
\text { height } \\
(\mathrm{cm})\end{array}$ & $\begin{array}{l}\text { Shoot } \\
\text { weight } \\
\text { (g plant }^{-1} \text { ) }\end{array}$ & $\begin{array}{l}\text { Leaf } \\
\text { weight } \\
\left.\text { (g plant }^{-1}\right)\end{array}$ & $\begin{array}{l}\text { Leaf } \\
\text { area }\left(\mathrm{m}^{2}\right. \\
\left.\text { plant }^{-1}\right)\end{array}$ \\
\hline ICKM-1 & 47 & 8.88 & $13.64^{*}$ & 1285 & 49 & 11.98 & 14.70 & 1838 \\
\hline ICKM-4 & 44 & 7.82 & 9.79 & 1302 & 50 & 11.34 & 11.76 & 1867 \\
\hline ICKM-7 & 44 & 7.86 & 10.13 & $1500^{*}$ & 52 & 11.57 & 11.80 & 1831 \\
\hline ICKM-9 & 47 & 8.08 & 10.78 & $1611^{*}$ & $55^{*}$ & 11.75 & 12.11 & $2103^{*}$ \\
\hline ICKM-12 & $52^{*}$ & 11.35* & $13.50^{*}$ & $1545^{*}$ & 51 & $15.35^{*}$ & $16.05^{*}$ & $2142^{*}$ \\
\hline ICKM-14 & $51 *$ & $11.28^{*}$ & $13.63^{*}$ & $1601^{*}$ & 51 & 12.48 & $14.05^{*}$ & 1931 \\
\hline ICKM-15 & 45 & 7.88 & 9.82 & $1493^{*}$ & 51 & 12.04 & 11.14 & 1844 \\
\hline ICKM-17 & $53^{*}$ & 8.09 & 9.47 & $1481^{*}$ & 50 & 12.04 & 11.04 & 1846 \\
\hline ICS-30 & 46 & 7.84 & 10.10 & 1331 & 49 & 11.86 & 11.38 & 1831 \\
\hline ICS-31 & 46 & 7.85 & 9.45 & 1151 & 49 & 11.46 & 11.34 & 1838 \\
\hline ICS-32 & 45 & 7.95 & 11.06 & 1240 & 52 & $14.12^{*}$ & $17.16^{*}$ & 2081 \\
\hline Control & 44 & 7.60 & 9.13 & 1112 & 49 & 11.27 & 11.11 & 1798 \\
\hline Mean & 47 & 8.54 & 10.88 & 1388 & 51 & 12.27 & 12.080 & 1913 \\
\hline $\mathrm{SE} \pm$ & 1.9 & 0.861 & 0.989 & 101.8 & 1.1 & 0.778 & 1.173 & 68.6 \\
\hline LSD (5\%) & 5.7 & 2.524 & 2.812 & 298.5 & 3.1 & 2.294 & 3.441 & 201.1 \\
\hline $\mathrm{CV} \%$ & 7 & 18 & 15 & 13 & 4 & 11 & 16 & 16 \\
\hline
\end{tabular}

$\mathrm{SE}=$ Standard error; LSD = least significant differences; $\mathrm{CV}=$ coefficients of variation; * = statistically significant at 0.05 compared to control.

12, ICKM-14, ICKM-15, ICKM-17, ICS-30, ICS-31 and ICS-32 were found maximum identity with Pantoea dispersa, Chryseobacterium indologenes, Pseudomonas geniculata, Stenotrophomonas pavanii, P. geniculata, $P$. geniculata, Stenotrophomonas maltophilia, Chryseobacterium sp., $P$. geniculata, Chryseobacterium indologenes and Stenotrophomonas acidaminiphila, respectively. The nucleotide sequences of all the 11 root nodule bacteria were submitted to GenBank and NCBI accession numbers were obtained as follows: ICKM-1:KX583493; ICKM-4:KX583496; ICKM-7:KX583495; ICKM-9:KX583494; ICKM-12:KX583492; ICKM14:KX611373; ICKM-15:KX611374; ICKM-17:KX611375; ICS30:KX611376; ICS-31:KY800376 and ICS-32:KX611377.

\section{Discussion}

In the past, bacteria isolated from nodules were always considered as rhizobia, however, in the recent past, an increasing number of $\alpha$ - $\beta$ and $\gamma$-Proteobacteria have been reported from nodules of wide range of legumes and reported as nodulating bacteria (Moulin et al., 2001; Vandamme et al., 2002; Valverde et al., 2005; Lin et al., 2008; Saidi et al., 2013). These non-symbiotic nodulating bacteria, isolated from nodules, also establish beneficial interactions with plants (Saidi et al., 2013; Verma et al., 2014; Gopalakrishnan et al., 2015b). However, they have not been studied well as compared to symbiotic bacteria from nodules. In the present investigation, a total of 11 root nodule bacteria were isolated from the root nodules of two chickpea cultivars. In order to test their nitrogen fixing ability, genomic DNA of the isolates was used for amplification of the nifH gene. All the 11 bacterial isolates were found to have the nitrogen fixing genes and nodulated the chickpea plants under greenhouse conditions. Further, the nitrogenase activity of the 11 root nodule bacteria were also demonstrated by ARA which is an indirect method to quantify biological nitrogen fixation (BNF) since it measures the conversion of acetylene to ethylene by the nitrogenase enzymes similar to the reduction of $\mathrm{N}_{2}$ to $\mathrm{NH}_{3}$ by diazotrophs. Nitrogenase enzymes are important as these are the only family of enzymes known to catalyze this reaction, which is a key step in the process of nitrogen fixation. In the present study, the nitrogenase activity was recorded in the range of $0.447-4.920$ nmoles of ethylene $\mathrm{g}^{-1}$ fresh nodules $\mathrm{h}^{-1}$ (Table 1), with highest activity in ICKM-9 followed 
Table 4

Effect of the 11 PGP bacteria on yield performance on two chickpea cultivars under field conditions- at crop maturity.

\begin{tabular}{|c|c|c|c|c|c|c|c|c|c|c|}
\hline \multirow[b]{2}{*}{ Isolate } & \multicolumn{5}{|l|}{ ICCV-2 } & \multicolumn{5}{|l|}{ JG-11 } \\
\hline & $\begin{array}{l}\text { Pod } \\
\text { number } \\
\text { (plant }^{-1} \text { ) }\end{array}$ & $\begin{array}{l}\text { Pod } \\
\text { weight } \\
\text { (g plant }^{-1} \text { ) }\end{array}$ & 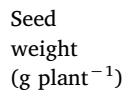 & $\begin{array}{l}\text { Grain } \\
\text { yield } \\
\left.\text { (t ha }^{-1}\right)\end{array}$ & $\begin{array}{l}\text { Stover } \\
\text { yield } \\
\left(\mathrm{t} \mathrm{ha}^{-1}\right)\end{array}$ & $\begin{array}{l}\text { Pod } \\
\text { number } \\
\text { (plant }^{-1} \text { ) }\end{array}$ & $\begin{array}{l}\text { Pod } \\
\text { weight } \\
\text { (g plant }^{-1} \text { ) }\end{array}$ & 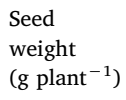 & $\begin{array}{l}\text { Grain } \\
\text { yield } \\
(\mathrm{g})\left(\mathrm{t} \mathrm{ha}^{-1}\right)\end{array}$ & $\begin{array}{l}\text { Stover } \\
\text { yield } \\
\left(\mathrm{t} \mathrm{ha}^{-1}\right)\end{array}$ \\
\hline ICKM-1 & $58^{*}$ & $18.17^{*}$ & $14.62^{*}$ & 1.979 & 1.903 & $77 *$ & $22.89 *$ & $18.05^{*}$ & $3.108^{*}$ & 2.659 \\
\hline ICKM-4 & 49 & 15.81 & 12.04 & $2.229^{*}$ & 1.943 & $84 *$ & $25.07^{*}$ & $20.37^{*}$ & 2.910 & 2.601 \\
\hline ICKM-7 & $56^{*}$ & $19.89^{*}$ & $14.90 *$ & 1.828 & 1.873 & $79 *$ & $23.83^{*}$ & $19.65^{*}$ & 2.937 & 2.606 \\
\hline ICKM-9 & $57^{*}$ & $19.97^{*}$ & $14.37^{*}$ & 1.894 & 1.864 & $72 *$ & $23.00^{*}$ & $17.84^{*}$ & $3.300 *$ & $2.811^{*}$ \\
\hline ICKM-12 & $55^{*}$ & $19.12^{*}$ & $15.19^{*}$ & $2.123^{*}$ & 1.873 & $76^{*}$ & $23.86^{*}$ & $19.56^{*}$ & $3.316^{*}$ & $2.792^{*}$ \\
\hline ICKM-14 & $62^{*}$ & $20.31 *$ & $15.17^{*}$ & $2.119^{*}$ & $2.140^{*}$ & $80 *$ & $24.15^{*}$ & $19.65^{*}$ & $3.170^{*}$ & 2.630 \\
\hline ICKM-15 & 48 & 15.02 & 11.64 & 1.860 & 1.830 & $74 *$ & $24.02^{*}$ & $18.96^{*}$ & $3.013^{*}$ & 2.688 \\
\hline ICKM-17 & $57^{*}$ & $19.10^{*}$ & $14.62^{*}$ & $2.138^{*}$ & $2.160 *$ & $74 *$ & $21.17^{*}$ & $17.33^{*}$ & $3.462 *$ & 2.657 \\
\hline ICS-30 & $56^{*}$ & $18.18^{*}$ & $14.25^{*}$ & $2.191^{*}$ & $2.024^{*}$ & 68 & 19.78 & 15.72 & $3.209^{*}$ & 2.682 \\
\hline ICS-31 & 53 & $18.45^{*}$ & 12.71 & 1.996 & 1.892 & $69 *$ & 20.87 & 16.93 & $3.061 *$ & $2.802^{*}$ \\
\hline ICS-32 & $59 *$ & $18.84 *$ & $13.98^{*}$ & $2.455^{*}$ & $2.366^{*}$ & $71 *$ & 20.81 & 16.84 & $3.398^{*}$ & $2.758^{*}$ \\
\hline Control & 46 & 14.70 & 10.69 & 1.803 & 1.786 & 58 & 16.41 & 13.47 & 2.602 & 2.595 \\
\hline Mean & 55 & 18.13 & 13.68 & 2.051 & 1.971 & 74 & 22.16 & 17.86 & 3.124 & 2.690 \\
\hline $\mathrm{SE} \pm$ & 2.8 & 1.153 & 0.958 & 0.121 & 0.099 & 3.8 & 1.627 & 1.274 & 0.141 & 0.051 \\
\hline LSD (5\%) & 8.3 & 3.381 & 2.811 & 0.356 & 0.292 & 11.1 & 4.772 & 3.737 & 0.415 & 0.149 \\
\hline CV\% & 9 & 11 & 12 & 10 & 9 & 9 & 13 & 12 & 8 & 3 \\
\hline
\end{tabular}

$\mathrm{SE}=$ Standard error; LSD = least significant differences; $\mathrm{CV}=$ coefficients of variation; * = statistically significant at 0.05 compared to control.

by ICKM-15, ICS-31 and ICS-32, which is more than $97 \%$ increase over the un-inoculated control. Kumar and Gera (2014) and Kayasth et al. (2014) reported nitrogen fixing ability of a diastrophic bacterium upon nifH gene amplification and acetylene reduction assay. In the present study, all the 11 root nodule bacteria significantly enhanced the shoot dry weight (up to $33 \%$ ), root dry weight (up to 64\%), total chlorophyll contents (up to $27 \%$; except ICKM-1), nodule number (up to $78 \%$ ) and nodule dry weight (up to 98\%) over the un-inoculated control (Table 1).

In field trial, all the 11 root nodule bacteria enhanced PGP and yield traits including nodule number, nodule weight, shoot weight, pod number, pod weight, seed weight, grain yield and stover yield in ICCV 2 and JG 11 varieties. Of the 11 root nodule bacteria, 7 (ICKM-1, ICKM-7, ICKM-12, ICKM-14, ICKM-15, ICKM-17 and ICS-30), 9 (except ICKM-7 and ICKM-14) and 6 (ICKM-12, ICKM-14, ICKM-17, ICS-30, ICS-31 and ICS-32) were found to enhance more than $10 \%$ nodule number, nodule weight and grain yield, respectively. The presence of PGP bacteria in the rhizosphere is known to enhance root and shoot growth, root hair development, nitrogen fixation, grain yield, stover yield, plant hormone regulation, solubilization of minerals and the suppression of pathogens in crops including pea, soybean and chickpea (Tokala et al., 2002; Lucas et al., 2009; Minorsky, 2008; Richardson et al., 2009; Soe et al., 2010; Gopalakrishnan et al., 2015a, 2016). However, reports on diazotrophic root nodule bacteria are very limited.

All the root nodule bacteria were found to produce cellulase, lipase, protease, IAA, $\beta-1,3$-glucanase, chitinase (except ICKM-1, ICKM-7, ICKM-15, ICS-30 and ICS-31), siderophore (except ICS-31) and HCN (except ICKM-17 and ICS-31) (Table 6). PGP bacteria are widely reported to stimulate plant growth by synthesizing growth hormones which lead to increased nutrient uptake and growth or induce systemic plant resistance against plant pathogens (Lippman et al., 1995; Liu et al., 1995). PGP bacteria such as Pseudomonas aeruginosa was reported to produce a maximum IAA of $45.53 \mu \mathrm{g} \mathrm{ml}^{-1}$ followed by Mesorhizobium sp. (34.15 $\left.\mu \mathrm{g} \mathrm{ml}^{-1}\right)$, Trichoderma harzianum $\left(25.89 \mu \mathrm{g} \mathrm{ml}^{-1}\right)$ and Azotobacter chroococcum (19.24 $\mu \mathrm{g} \mathrm{ml}^{-1}$ ) (Verma et al., 2014) whereas in the present study, 6 isolates produced 4-8 times more IAA compared to those reported above. These six isolates, ICKM-1, ICKM-9, ICKM-12, ICKM-14, ICS-30 and ICS-32, were found to produce more than $90 \mu \mathrm{g} \mathrm{mg}^{-1}$ of IAA and of which, ICKM-14 produced the maximum $\left(339 \mu \mathrm{g} \mathrm{mg}^{-1}\right)$ IAA followed by ICS-32 (165 $\left.\mu \mathrm{g} \mathrm{mg}^{-1}\right)$, ICKM-9

Table 5

Effect of the 11 PGP bacteria on soil nutrient traits on two chickpea cultivars under field conditions- at crop maturity.

\begin{tabular}{|c|c|c|c|c|c|c|}
\hline \multirow[b]{2}{*}{ Isolate } & \multicolumn{3}{|l|}{ ICCV-2 } & \multicolumn{3}{|l|}{ JG-11 } \\
\hline & $\begin{array}{l}\text { Organic } \\
\text { carbon (\%) }\end{array}$ & $\begin{array}{l}\text { Total N } \\
(\mathrm{ppm})\end{array}$ & $\begin{array}{l}\text { Available P } \\
\text { (ppm) }\end{array}$ & $\begin{array}{l}\text { Organic } \\
\text { carbon \% }\end{array}$ & $\begin{array}{l}\text { Total N } \\
\text { (ppm) }\end{array}$ & $\begin{array}{l}\text { Available P } \\
\text { (ppm) }\end{array}$ \\
\hline ICKM-1 & 0.47 & $727^{*}$ & 4.85 & 0.42 & $795^{*}$ & $5.76^{*}$ \\
\hline ICKM-4 & 0.48 & $713^{*}$ & 4.96 & $0.52^{*}$ & $780^{*}$ & $5.13^{*}$ \\
\hline ICKM-7 & 0.48 & $709 *$ & 4.83 & 0.44 & 670 & 4.42 \\
\hline ICKM-9 & 0.48 & 674 & 4.99 & $0.56^{*}$ & 677 & $5.84^{*}$ \\
\hline ICKM-12 & 0.47 & 675 & $5.53^{*}$ & 0.46 & 654 & 4.23 \\
\hline ICKM-14 & $0.49 *$ & 664 & 4.83 & 0.43 & 656 & 4.27 \\
\hline ICKM-15 & 0.48 & 663 & 4.98 & 0.44 & 662 & 4.66 \\
\hline ICKM-17 & $0.50 *$ & 668 & 5.13 & 0.47 & 686 & 4.73 \\
\hline ICS-30 & 0.47 & 678 & 4.75 & $0.52^{*}$ & 655 & 4.28 \\
\hline ICS-31 & $0.49 *$ & $723^{*}$ & 4.83 & 0.44 & 675 & 4.55 \\
\hline ICS-32 & $0.51 *$ & $738^{*}$ & $5.30 *$ & 0.44 & 666 & 4.36 \\
\hline Control & 0.47 & 655 & 4.75 & 0.42 & 642 & 4.16 \\
\hline Mean & 0.48 & 690 & 4.98 & 0.46 & 685 & 4.70 \\
\hline $\mathrm{SE} \pm$ & 0.008 & 17.2 & 0.134 & 0.019 & 24.2 & 0.277 \\
\hline LSD (5\%) & 0.023 & 53.6 & 0.416 & 0.060 & 74.5 & 0.863 \\
\hline $\mathrm{CV} \%$ & 2 & 4 & 4 & 6 & 5 & 8 \\
\hline
\end{tabular}

$\mathrm{SE}=$ Standard error; LSD = least significant differences; $\mathrm{CV}=$ coefficients of variation; * = Statistically significant at 0.05 compared to control. 
Table 6

Enzymatic activities and metabolite production by the 11 PGP bacterial isolates from the nodules of chickpea.

\begin{tabular}{|c|c|c|c|c|c|c|c|c|c|}
\hline \multirow[b]{2}{*}{ Isolate } & \multicolumn{9}{|c|}{ At $72 \mathrm{~h}$, production of } \\
\hline & $\begin{array}{l}\text { Cellulase } \\
(\mathrm{mm})\end{array}$ & $\begin{array}{l}\text { Lipase } \\
(\mathrm{mm})\end{array}$ & $\begin{array}{l}\text { Protease } \\
(\mathrm{mm})\end{array}$ & $\begin{array}{l}\text { PS } \\
(\mathrm{mm})\end{array}$ & $\begin{array}{l}\text { Chitinase } \\
(\mathrm{mm})\end{array}$ & $\begin{array}{l}\text { IAA } \\
(\mu \mathrm{g} / \mathrm{ml})\end{array}$ & $\begin{array}{l}\beta-1,3 \text {-glucanase } \\
\text { units }^{@}\end{array}$ & $\begin{array}{l}\text { Sid. } \\
\text { units }\end{array}$ & $\mathrm{HCN}^{\#}$ \\
\hline ICKM-1 & 27 & 22 & 21 & 0 & 0 & 111 & 2.54 & 45 & 3 \\
\hline ICKM-4 & 27 & 25 & 29 & 0 & 16 & 9 & 2.03 & 67 & 1 \\
\hline ICKM-7 & 24 & 25 & 21 & 8 & 0 & 10 & 1.19 & 65 & 1 \\
\hline ICKM-9 & 26 & 20 & 26 & 10 & 18 & 145 & 1.63 & 46 & 1 \\
\hline ICKM-12 & 25 & 20 & 25 & 6 & 12 & 93 & 1.64 & 48 & 2 \\
\hline ICKM-14 & 25 & 20 & 22 & 0 & 13 & 339 & 1.75 & 30 & 1 \\
\hline ICKM-15 & 25 & 25 & 27 & 10 & 0 & 10 & 1.73 & 64 & 3 \\
\hline ICKM-17 & 26 & 20 & 25 & 0 & 20 & 8 & 2.69 & 72 & 0 \\
\hline ICS-30 & 27 & 30 & 29 & 10 & 0 & 115 & 1.33 & 34 & 1 \\
\hline ICS-31 & 24 & 25 & 25 & 10 & 0 & 27 & 1.07 & 0 & 0 \\
\hline ICS-32 & 18 & 25 & 10 & 0 & 16 & 165 & 1.37 & 44 & 3 \\
\hline Mean & 25 & 23 & 24 & 5 & 9 & 94 & 1.72 & 47 & 2 \\
\hline $\mathrm{SE} \pm$ & $0.2^{* * * *}$ & $0.5^{* * * k}$ & $0.2^{* * * k}$ & $0.1^{* * * k}$ & $0.2^{* * * k}$ & $14.8^{* * * *}$ & $0.075^{* * * k}$ & $1.6^{* * * *}$ & 0 \\
\hline LSD (5\%) & 0.7 & 1.5 & 0.5 & 0.3 & 0.6 & 43.7 & 0.222 & 4.7 & 0 \\
\hline CV\% & 2 & 4 & 1 & 4 & 4 & 27 & 8 & 6 & 0 \\
\hline
\end{tabular}

PS = Phosphate solubilization; Sid. = Siderophore.

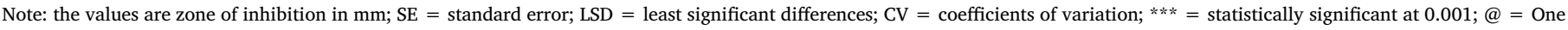

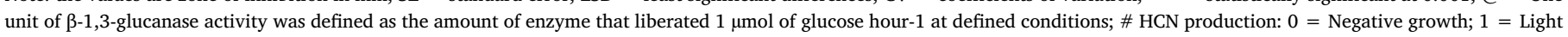
growth; 2 = Moderate growth; 3 = Good growth.

(145 $\left.\mu \mathrm{g} \mathrm{m}^{-1}\right)$, ICS-30 (115 $\left.\mu \mathrm{g} \mathrm{mg}^{-1}\right)$ and ICS-1 (111 $\left.\mu \mathrm{g} \mathrm{mg}^{-1}\right)$. IAA producing bacteria are reported to stimulate seed germination, root formation and plant growth and thereby provides the host plant greater access to water and nutrients (Ahemad and Kibret, 2014).
Siderophores are reported as solubilizing agents for iron under conditions of iron limitation (Indiragandhi et al., 2008). HCN is reported to play a role in disease suppression in tobacco, where HCN producing Pseudomonas fluorescens suppressed black root rot disease

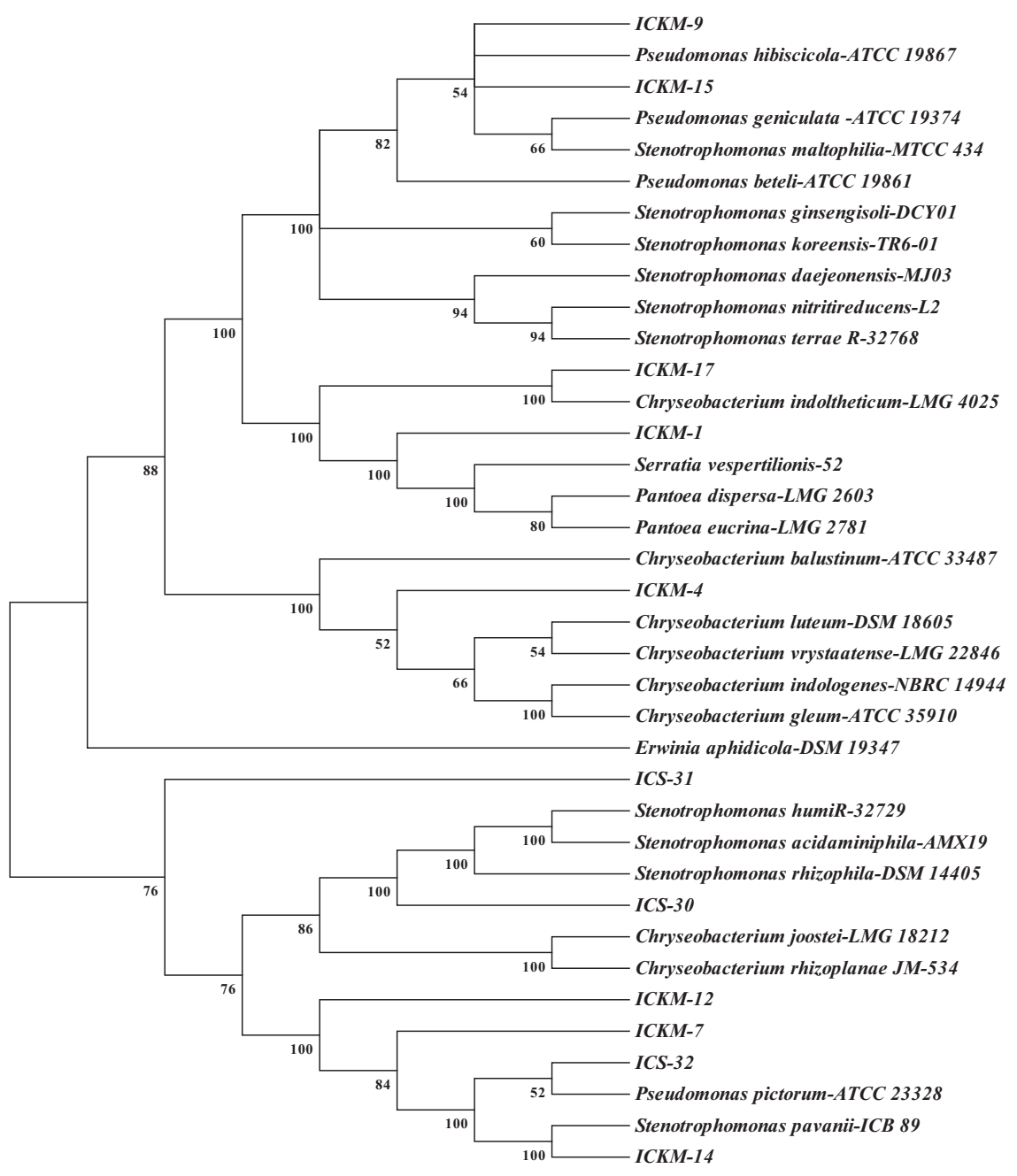

Fig. 1. Phylogenetic relationship between the eleven PGP potential bacteria and representative species based on full length 16S rDNA sequences constructed using the neighbor-joining method. 
(Haas et al., 1991). Protease and cellulase-producing bacteria are reported to play an important role in the nutrient mineralization and PGP (Lima et al., 1998). $\beta$-1,3-glucanase-producing bacteria are reported to leak the cell wall contents and collapse Fusarium oxysporum (Singh et al., 1999). In the present study, $6 / 11$ root nodule bacteria also solubilized phosphorous (except ICKM-1, ICKM-4, ICKM-14, ICKM-17 and ICS-32). Phosphorous (P) is one of the three macronutrients essential for plant growth. It is abundant in many agricultural soils but it is unavailable to plants due to low level of soluble phosphate. Phosphatesolubilizing bacteria such as Burkholderia cepacia are reported to be effective in releasing $\mathrm{P}$ from total soil $\mathrm{P}$ through mineralization and solubilization (Zhao et al., 2014). In the present study, the mechanisms by which the isolates promote plant growth are not fully understood. However, their multiple modes of PGP traits may be responsible for growth promotion activities.

In the present study, all the 11 root nodule bacteria were identified up to species level by $16 \mathrm{~S}$ rDNA analysis. Of the 11 isolates, 4 were found to be Pseudomonas geniculata (ICKM-7, ICKM-12, ICKM-14 and ICS-30), 2 of Chryseobacterium indologenes (ICKM-4 and ICS-31), 1 of Chryseobacterium spp. (ICKM-17), 3 of Stenotrophomonas but different species (ICKM-9, ICKM-15 and ICS-32) and one of Pantoea dispersa (ICKM-1).

Plant-microbe interaction involves colonization by a variety of PGP microbes, in and around the roots, in associative or symbiotic relations within the plant. The usefulness of this interaction largely depends on the type of PGP microbes involved, plant defence system environment and soil nutrient status. The 11 diazotrophic root nodule bacteria demonstrated in this study, for their nitrogen fixation, PGP and yield enhancement traits, could be co-inoculated with Mesorhizobium sp. of chickpea. PGP bacteria co-inoculated with Mesorhizobium sp. was reported to significantly enhance nodulation, nitrogen fixation, $\mathrm{P}$ and $\mathrm{Fe}$ acquisition, plant growth and yield traits in chickpea under both pot as well as field conditions (Valverde et al., 2006; Verma et al., 2013). Synergistic consortia of Mesorhizobium sp. and PGP bacteria with various metabolic traits such as nitrogen fixation, phosphorous mobilization, synthesis of growth hormones and secondary metabolites can be better than single inoculations. The application of such PGP bacteria as inoculants for bio-fertilization, biocontrol and biofortification would be an alternative to reduce the use of synthetic fertilizers and pesticides which effect environmental contamination and/or pollution. The diazotrophic strains used in this study will ultimately help in the development of biofertilizers for use in semi-arid soils to increase the availability of nutrients for both growth and yield of chickpea.

\section{Conflict of interest}

All the authors declare that they have no financial/commercial conflicts of interest.

\section{Acknowledgements}

This work has been undertaken as part of the CGIAR Research Program on Grain Legumes. ICRISAT is a member of CGIAR Consortium. We thank all the staff of the Biocontrol unit of ICRISAT including M/s PVS Prasad, P Manohar and A Jabbar for their significant contribution in the laboratory and field studies.

\section{References}

Ahmad, F., Ahmad, I., Khan, M.S., 2008. Screening of free-living rhizospheric bacteria for their multiple plant growth-promoting activities. Microb. Res. 163, 173-181.

Ahemad, M., Kibret, M., 2014. Mechanisms and applications of plant growth-promoting rhizobacteria: current perspective. J. King Saud. Univ, 26, 1-20.

Altschul, S.F., Gish, W., Miller, W., Myers, E.W., Lipman, D.J., 1990. Basic local alignment search tool. J. Mol. Biol. 215, 403-410.

Awasthi, C.P., Abidi, A.B., Chowdhury, A.R., 1991. Studies on the nutritional quality of different varieties of chickpea. Ind. J. Agric. Res. 25, 21-26.
Bazzicalupo, M., Fani, R., 1995. The use of RAPD for generating specific DNA probes for microorganisms. In: Clap., J.P. (Ed.), Methods in Molecular Biology, Species Diagnostic Protocols: PCR and Other Nucleic Acid Methods. Humana Press Inc, Totowa NJ, pp. 112-124.

Bhattacharya, A., Chandra, S., Barik, S., 2009. Lipase and protease producing microbes from the environment of sugar beet field. Ind. J. Agric. Biochem. 22, 26-30.

FAOSTAT, 2017. Statistical Database 2017. Available at 〈http://faostat.fao.org $\rangle$.

Gopalakrishnan, S., Srinivas, V., Alekhya, G., Prakash, B., Kudapa, H., Varshney, R.K., 2015a. Evaluation of Streptomyces sp. obtained from herbal vermicompost for broad spectrum of plant growth-promoting activities in chickpea. Org. Agric. 5, 123-133.

Gopalakrishnan, S., Srinivas, V., Prakash, B., Vijayabharathi, R., Rupela, O., 2014. Evaluation of Streptomyces strains isolated from herbal vermicompost for their plant growth-promotion traits in rice. Microbiol. Res. 169, 40-48.

Gopalakrishnan, S., Srinivas, V., Prakash, B., Sathya, A., Vijayabharathi, R., 2015b. Plant growth-promoting traits of Pseudomonas geniculata isolated from chickpea nodules. 3Biotech 5, 653-661.

Gopalakrishnan, S., Srinivas, V., Srinivasan, S., Sameer Kumar, C.V., 2016. Plant growth promotion and biofortification of chickpea and pigeonpea through inoculation of biocontrol potential bacteria, isolated from organic soils. SpringerPlus 5, 1882.

Haas, D., Keel, C., Laville, J., Maurhofer, M., Oberhansli, T., Schnider, U., Voisard, C., Wuthrich, B., Defago, G., 1991. Secondary metabolites of Pseudomonas fluorescens strain CHAO involved in the suppression of root diseases. In: In: Hennecke, H., Verma, D.P.S. (Eds.), Advances in Molecular Genetics of Plant-Microbe Interactions, vol. 11. Kluwer Academic Publishers, pp. 450-456.

Hardy, R.W.E., Holstein, R.W., Jackson, E.K., Burns, R.C., 1968. The acetylene ethylene assay for nitrogen fixation. Lab. Field Eval. Plant Physiol. 43, 1185-1207.

Hendricks, C.W., Doyle, J.D., Hugley, B., 1995. A new solid medium for enumerating cellulose-utilizing bacteria in soil. Appl. Environ. Microbiol. 61, 2016-2019.

Hiscox, J.D., Israelstam, G.F.A., 1979. A method for the extraction of chlorophyll from leaf tissue without maceration. Can. J. Bot. 57, 1332-1334.

Hsu, S.C., Lockwood, J.L., 1975. Powdered chitin agar as a selective medium for enumeration of actinomycetes in water and soil. J. Appl. Microbiol. 29, 422-426.

Indiragandhi, P., Anandham, R., Madhaiyan, M., Sa, T.M., 2008. Characterization of plant growth-promoting traits of bacteria isolated from larval guts of diamondback moth Plutella xylostella (Lepidoptera; Plutellidae). Curr. Microbiol. 56, 327-333.

Kayasth, M., Kumar, V., Gera, R., 2014. Gordonia sp.: a salt tolerant bacterial inoculant for growth promotion of pearl millet under saline soil conditions. 3Biotech 4, 553-557.

Kloepper, J.W., Schroth, M.N., 1978. Plant growth-promoting rhizobacteria on radishes. In: Proceedings of the 4th international conference on plant pathogenic bacteria, vol 2. Station de Pathologie Ve'ge'tale et de Phytobacte'riologie, INRA, Angers, France, pp. 879-882.

Kumar, V., Gera, R., 2014. Isolation of a multi-trait plant growth-promoting Brevundimonas sp. and its effect on the growth of Bt-cotton. 3Biotech 4 (1), 97-101.

Lima, L.H.C., Marco, J.L., Felix, J.R., 1998. Enzimas hidroliticas envolvidas no controle biologico por miciparasitisma. In: In: Melo, I.S., Azevedo, J.L. (Eds.), Controle biologico 11. EMBRAPA-Meio Ambiente, Jaguraiuna, pp. 263-304.

Lin, D.X., Wang, E.T., Tang, H., Han, T.X., He, Y.R., Guan, S.H., Chen, W.X., 2008. Shinella kummerowiae sp. nov., a symbiotic bacterium isolated from root nodules of the herbal legume Kummerowia stipulacea. Int. J. Syst. Evol. Microbiol. 58, 1409-1413.

Lippman, B., Leinhos, V., Bergmann, H., 1995. Influence of auxin producing rhizobacteria on root morphology and nutrient accumulation of crops. Changes in root morphology and nutrient accumulation in maize (Zea mays L.) caused by inoculation with indole3-acetic acid (IAA) producing Pseudomonas and Acinetobacter strains of IAA applied exogenously. Angew. Bot. 69, 31-36.

Liu, L., Kloepper, J.W., Tuzun, S., 1995. Induction of systemic resistance in cucumber against Fusarium wilt by plant growth-promoting rhizobacteria. Phytopathology 85, 695-698.

Lorck, H., 1948. Production of hydrocyanic acid by bacteria. Plant Physiol. 1, 142-146.

Lucas, J.A., Solano, B.R., Montes, F., Ojeda, J., Megias, M., Manero, F.J.G., 2009. Use of two PGPR strains in the integrated management of blast disease in rice (Oryza sativa) in Southern Spain. Field Crops Res. 114, 404-410.

Minorsky, P.V., 2008. On the inside. Plant Physiol. 146, 323-324.

Moulin, L., Munive, A., Dreyfus, B., Boivin-Masson, C., 2001. Nodulation of legumes by members of the $\beta$-subclass of Proteobacteria. Nature 411, 948-950.

Nautiyal, C.S., 1999. An efficient microbiological growth medium for screening phosphate solubilizing microorganisms. FEMS Microbiol. Lett. 170, 265-270.

Nelson, D.W., Sommers, L.E., 1982. Total organic carbon and organic matter. In: Page, A.L., Miller, R.H., Keeney, D.R. (Eds.), Methods of Soil Analysis, Part 3, Chemical and Microbiological Properties. SSSA, Madison, WI, pp. 539-579.

Novozamsky, I., Houba, V.J.G., Van, E.C.K.R., vanVark, W., 1983. A novel digestion technique for multiple element analysis. Commun. Soil Sci. Plant Anal. 14, 239-249.

Olsen, S.R., Sommers, L.E., 1982. Phosphorus. In: Page, A.L. (Ed.) Methods of Soil Analysis, Agron. No 9, Part 2, 'Chemical and Microbial Properties', 2nd edition, Am Soc. Agron. Madison WI, USA, pp. 403-430.

Patten, C., Glick, B.R., 2002. Role of Pseudomonas putida in indole acetic acid in development of host plant root system. Appl. Environ. Microbiol. 68, 3795-3801.

Richardson, A.E., Barea, J.M., Mcneill, A.M., Combaret, C.P., 2009. Acquisition of P and $\mathrm{N}_{2}$ in the rhizosphere and plant growth-promotion by microorganisms. Plant Soil 321, 305-339.

Rupela, O.P., Gupta, A.P., Kapoor, K.K., 2005. Is high yield possible with biological approaches? In: Kapoor, K.K., Sharma, P.K., Dudeja, S.S., Kundu, B.S. (Eds.), Management of Organic Wastes for Crop Production, pp. 193-203.

Saidi, S., Chebil, S., Gtari, M., Mhamdi, R., 2013. Characterization of root-nodule bacteria isolated from Vicia faba and selection of plant growth-promoting traits. World J. Microbiol. Biotechnol. 29, 1099-1106.

Saitou, N., Nei, M., 1987. The neighbour-joining method: a new method for 
reconstructing phylogenetic trees. Mol. Biol. 4, 406-425.

Sarita, S., Priefer, U., Prell, J., Sharma, P.K., 2007. Diversity of nifH gene amplified from rhizosphere soil DNA. Curr. Sci. 94, 109-114.

Schwyn, B., Neilands, J.B., 1987. Universal chemical assay for the detection and determination of siderophore. Annu. Biochem. 160, 47-56.

Singh, N., Pandey, P., Dubey, R.C., Maheshwari, D.K., 2008. Biological control of root rot fungus Macrophomina phaseolina and growth enhancement of Pinus roxburghii by rhizosphere competent Bacillus subtilis BN1. World J. Microbiol Biotechnol. 24, 1669-1679.

Singh, P.P., Shin, Y.C., Park, C.S., Chung, Y.R., 1999. Biological control of Fusarium wilt of cucumber by chitinolytic bacteria. Phytopathol 89, 92-99.

Soe, K.M., Bhromsiri, A., Karladee, D., 2010. Effects of selected endophytic actinomycetes (Streptomyces sp.) and Bradyrhizobia from Myanmar on growth, nodulation, nitrogen fixation and yield of different soybean varieties. CMU J. Nat. Sci. 9, 95-109.

Sreevidya, M., Gopalakrishnan, S., 2017. Direct and indirect plant growth-promoting abilities of Bacillus species on chickpea, isolated from compost and rhizosphere soils. Org. Agric. 7, 31-40.

Thompson, J.D., Gibsom, T.J., Plewniak, F., Jeanmougin, F., Higgins, D.G., 1997. The clustal $\mathrm{X}$ windows interface: flexible strategies for multiple sequence alignment aided by quality analysis tools. Nucleic Acids Res. 24, 4876-4882.

Tokala, R.K., Strap, J.L., Jung, C.M., Crawford, D.L., Salove, M.H., Deobald, L.A., Bailey, J.F., Morra, M.J., 2002. Novel plant-microbe rhizosphere interaction involving Streptomyces lydicus WYEC108 and the pea plant (Pisum sativum). Appl. Environ. Microbiol. 68, 2161-2171.

Uren, N.C., 2000. Types, amounts and possible functions of compounds released into the rhizosphere by soil-grown plants. In: Pinto, R., Varanini, Z., Nannipieri, P. (Eds.), The Rhizosphere: Biochemistry and Organic Substances at the Soil-plant Interface. Marcel
Dekker, New Yark, pp. 19-40.

Valverde, A., Velazquez, E., Fernandez-Santos, F., Vizcaino, N., Rivas, R., Mateosn, P.F., Martinez- Molina, E., Igual, J.M., Willems, A., 2005. Phyllobacterium trifolii sp. nov., nodulating Trifolium and Lupinus in Spanish soils. Int. J. Syst. Evol. Microbiol 55, 1985-1989.

Valverde, A., Burgos, A., Fiscella, T., Rivas, R., Velazquez, E., Rodriguez-Barrueco, C., Cervantes, E., Chamber, M., Igual, J.M., 2006. Differential effects of co-inoculation with Pseudomonas jessenii PS06 (a phosphate solubilizing bacteria) and Mesorhizobium ciceri $\mathrm{C}-2 / 2$ strains on the growth and seed yield of chickpea under greenhouse and field conditions. Plant Soil 287, 43-50.

Vandamme, P., Henry, D., Coenye, T., Nzula, S., Vancanneyt, M., LiPuma, J.J., Spert, D.P., Govan, J.R., Mahenthiralingam, E., 2002. Burkholderia anthina sp. nov. and Burkholderia pyrrocinia, two additional Burkholderia cepacia complex bacteria, may confound results of new molecular diagnostic tools. FEMS Immunol. Med. Microbiol. 33, 143-149.

Verma, J.P., Yadav, J., Tiwari, K.N., Jaiswal, D.K., 2014. Evaluation of plant growthpromoting activities of microbial strains and their effect on growth and yield of chickpea (Cicer arietinum L.) in India. Soil Biol. Biochem. 70, 33-37.

Verma, J.P., Yadav, J., Tiwari, K.N., Kumar, A., 2013. Effect of indigenous Mesorhizobium spp. and plant growth-promoting rhizobacteria on yields and nutrients uptake of chickpea (Cicer arietinum L.) under sustainable agriculture. Ecol. Eng. 51, 282-286.

Weller, D.M., Raaijimakers, J.M., Gardners, B.B.M., Thomashow, L.S., 2002. Microbial population responsible for specific soil suppressiveness to plant pathogens. Ann. Rev. Phytopathol. 40, 309-348.

Zhao, K., Penttinen, P., Zhang, X., Ao, Z., Liu, M., Yu, X., Chen, Q., 2014. Maize rhizosphere in Sichuan, China, hosts plant growth-promoting Burkholderia cepacia with phosphate solubilizing and antifungal activities. Microbiol. Res. 169, 76-82. 